\title{
THE CATEGORY OF ACCIDENT IN NARRATIVES \\ ABOUT SALVATION \\ FROM EXTERMINATION
}

\begin{abstract}
There is a paradox about strange accidents - they happen again and again. Karel Čapek
\end{abstract}

In this article I will present examples of Polish modern narratives about salvation from extermination while placing emphasis on the category of accident. In most of these accounts accident is seen as a turning point in a narrative which breaks the plot in spite of all the recognized principles and which is related to the history or philosophy of life and accepted due to its saving nature. My intention is to interpret such an existential and narrative accident in light of narrative theories and systemics. The relationship between a grown-up narrator and a child who has experienced such an accident of salvation will be of special importance here. The temporal distance between such accounts allows one to talk about accident as an act of fortune which can be called a part of a greater whole.

Salvation narratives, which portray accident as an event that determines the course of fortune, have a kind of "systemic" character themselves. Perhaps all first-person narratives about the past, be they autobiographies or fiction, demonstrate such a tendency. However, it is especially noticeable in this case because of the multitude of examples and the similarity between the described circumstances. Thus, to some extent, this is a special case of showing the systemic approach as a way of perceiving the world. It can constitute a methodological basis for interpreting these descriptions too. 


\section{Systemics and the structural theory of narrative}

A certain coincidence can be observed in the humanities, also in the disciplines devoted to reflections on art, in the second half of the twentieth century. On the one hand, the structuralist orientation, which in the mid1960s started being superseded by poststructuralist tendencies, loses momentum; on the other hand, the systemic way of thinking clearly emerges from the maze of this methodological confusion. A number of similarities can be observed between structuralism, which stems from linguistics, and the systemic orientation, whose origin should be traced to sciences. It is characteristic that Ferdinand de Saussure should have used the term "system" and not "structure".

To put it in a nutshell, one can compare the ways in which these approaches present the relation of a part to the whole. In both of them the structure and parts of the system are interrelated by a network of ties. Also, each of these ties is related to the whole. A certain holistic nature of a structure or system assumes that it is a self-adjusting whole, i.e. any shift or replacement of a part impacts on the shape of the greater whole. At the same time, the overriding of one structure with another entails a mutation in the entire environment. Consequently, a structure and system are integrated arrangements which, at a given moment, constitute wholes that are dependent on the assumed or imposed study perspective (distance) and on the theory applied to the studied subject (interpretation).

The basic difference between structuralism and the theory of systems that can be pointed to constitutes a different approach to the subject of the study. While the former most often talks about a concrete object, the latter focuses on an attempt to formulate general models ${ }^{1}$. It is known, though, that also structuralism in its most scientific version tried to work out a certain model principle of operation of extant objects based on concrete artifacts and - by this token - a principle of generating new ones. This is most noticeable in the structural theory of narrative that was formulated by structuralists at the turn of the 1950s owing to, one must not forget, the thirty-year delayed reception of Morphology of the Folktale by Vladimir Propp. The act of singling out similar narrative texts, e.g. from one literary genre as well as a kind of plot template with recurring protagonists and a chain of events that those protagonists take part in, has strengthened the conviction that objects construed in this way constitute a certain system. This plot template was indeed an example emerging from a pool of examples treated as a whole, but at the same time it showed

${ }^{1}$ Cf. M. Ostrowicki, Dzieło sztuki jako system, Wydawnictwo Naukowe PWN, WarszawaKraków 1997, p. 15. 
potential for becoming a certain general model. One can talk then about the structural theory of narrative as the climax of structuralist research on literature as well as its convergence with systemics. As Roland Barthes and other authors explained in the proclaimed issue of the Communications magazine from 1966, each narrative can be compared to a sentence because it is made of a pool of reproducible elements (words) with the observance of the principles of joining them in higher-order units (grammar) ${ }^{2}$.

In this proposal, the reference to Propp (the way it was construed by a later generation of structuralists) is an attempt at transferring a concept originated from the theory of literature to various texts which are additionally marked with traumatic experiences that force one to see extermination as an "exceptional" event in the history of the human race. It is about showing that Propp's concept as well as its continuation pertains to general mechanisms - not only those found in folktales or even various literary genres - but in fact to human fortune, which is narrative in nature, as renowned modern thinkers, especially Paul Ricoeur, claim. Over time an accident, which is an event that, in a way, breaks such a narrative, becomes included in a story and defined not as a break, but as an accident of salvation.

\section{A template for a narrative}

The fact that Propp singled out an abstract system (a plot template and the principles governing it) from specific cultural texts has had a powerful impact on reflections on the functioning of a human being in history and in the context of his / her own biography. A reformulation of those studies, as necessitated by historiography or philosophical anthropology, bears strong witness to the fact that Morphology of the Folktale is one of the most important books in modern humanities. Naturally, documentary records about salvation from extermination and the related fictitious variations, especially when read on a large scale, are a specific object of reflection because they show primarily at the level of plot structures - many similarities. In this way Propp and Barthes' method (as expressed in a condensed form) takes on an almost palpable character of a reflection on human fortune. A kind of archetype appears in those studies as a sign of shared experience. This is what happens with stories about salvation. The consequences of the studies of texts refer one directly to reality and its various levels: an individual biographical experience as well as an existential and generation-specific collective experience (which

${ }^{2}$ Cf. W. Propp, Morfologia bajki, transl. by W. Wojtyga-Zagórska, Warszawa 1976; R. Barthes, Wstęp do analizy strukturalnej opowiadań, transl. by W. Błońska, „Pamiętnik Literacki” 1968, z. 4 . 
can be treated as collective only post factum because - eventually - only few have survived who are yet to talk about their salvation). If it were not a kind of paradox, one could state that the reading of the several dozen memories of the children of the Holocaust ${ }^{3}$, focused on the very event of salvation, almost leads to a conclusion pertaining to literary genres. Those stories, presented in a purely fictional mode and analyzed that way, show similarity already at the level of terminology or fiction-type resources (as for memories the question of purposeful literary tricks is, naturally, very questionable). Thus, every now and again a recurrent piece of information that can be found in such narratives is that "somebody was saved", "survived by a miracle", "escaped", "was found" or "found someone", and that something happened by "lucky coincidence"; finally, single events are directly called "accidents". Many fragments have a highly self-reflective character in this respect, for instance: "My autobiography is full of miraculous findings and unexpected results of looking for traces" [II 171], or:

All these are facts from my friends' biographies and accidents that could have happened to any of us. They are also a part of my history because they are a part of our history, although I have been spared these experiences personally [196].

Another source offers an account by Henryk Bryskier who survived his own execution by a firing squad. The accidental nature of this event is not directly mentioned, however, such a special moment is always stressed in this kind of traumatic memories:

Shots were fired and, at this very second, stifled by the cramp [of the heart], I fell senseless. My neighbour's brain splashed on my face and head. I am not sure whether they realized that the bullets had missed me or that the blood on my head was not mine, or maybe I moved. Anyway, one of the firing squad members came up to me and hit me with the butt end of his rifle on the forehead, over the eye. I treated the blow as a fired bullet and the blood as the result of being shot. Slowly I was coming back to my senses. I couldn't have possibly believed I was alive and being alive I believed I had died. (...) I lay, now consciously pretending to be dead, waiting for things to happen ${ }^{4}$.

Just for the sake of comparison, it is worth quoting a "literary" fragment. Here is a fragment from Zdażyć przed Panem Bogiem by Hanna Krall, a novelist and a reporter. The author quotes Marek Edelman, one of the leaders of the Warsaw Ghetto Uprising:

${ }^{3}$ The Polish edition - in two volumes - contains almost a hundred memories. This is obviously only a part of a collection of this type, published or otherwise disseminated, to be found in various archives of the world. Dzieci Holocaustu mówiq..., vol. I, ed. W. Śliwowska, Warszawa 1993; vol. II, ed. J. Gutenbaum, A. Latała, Warszawa 2001 (references to this item can be found directly in the text).

${ }^{4}$ Quote after: J. Leociak, Tekst wobec Zagłady (O relacjach z getta warszawskiego), Wydawnictwo Leopoldinum, Wrocław 1997, p. 234. 
This is the second example: he should certainly have died, but was saved by accident. For the first time he was saved owing to the SS officer's astigmatism and now by the fact that Mietek Dąb, who was coming back from work, was walking down the street ${ }^{5}$.

The novel by Adam Sikora Szczęściarz is the essence of narrative about salvation in which accident plays an important role. This book is special as the author talks, without any direct reference to accident, about his war-time fortunes as a Jewish child as a series of fortunate events, which were sometimes provoked (the necessary deceptions of a small protagonist) and sometimes unexpected.

At that time a moment was important, only a moment, every consecutive moment, another moment and nothing else... Perhaps this is the reason I survived..., because I was able to get rid of principles, scruples and not care about others, concentrating fully on my own survival, making use of all there was, every opportunity and every person ${ }^{6}$.

This convention, if one can use this word, of narrative about lucky coincidences also appears in the memories of the children of the Holocaust: Jerzy Frydman's [I 49-53], Henoch Rafael Lisak's [I 79-83] or Janina Pietrasiak's, who stresses in the title: "I am one of the lucky ones", and emphasizes that she owes her life to a "chain of people of goodwill" [II 146].

The most conspicuous narrative method in stories about salvation is the use of the subjunctive and the question: what would have happened if? [II 20]. Two examples: "I looked carefully where we were going. If the truck turns towards the Gestapo, I am dead. Fortunately, the truck went directly to Arbeitsamt" [I 32]; "One day two trams came at the same time, one after the other. I got on the first one and I was lucky because an SS squad stopped the other tram and arrested all the passengers" [II 17]. In order to show a certain "genre" of those narratives and the type of repeatability which is a constitutive element of this genre, one can once more refer to a literary text. Ida Fink, a writer who died on 27 September 2011, wrote the following in her Podróż (a mini-autobiographical novel):

Another hour will pass - an hour of interrogation - before we find ourselves on the edge of an abyss, before a tall and slim military policeman, with the face of a bird of prey dials the number of the Gestapo and before blind fate makes him stop and hang up $^{7}$ [underlined by R.K.].

From the point of view of this discussion the remarks of the saved about the repeatability of their fate are of special interest: "As always, accident - but

\footnotetext{
${ }^{5}$ H. Krall, Zdą̇yć przed Panem Bogiem, GAMMA, Warszawa 1992, p. 130.

${ }^{6}$ A. Sikora, Szczęściarz, Twój Styl, Warszawa 2001, p. 85.

7 I. Fink, Podróż, Aneks, London 1990, p. 156.
} 
also people's kindness - allowed him [father - R.K.] walk that way with us" [I 201]; "My next fortunes were quite similar to those of many saved children I had a foster family" [II 149]. Finally, a quotation I personally would consider the most important because, in addition to pointing to the role played by accident, it highlights a motif that is vital from the point of view of a systemic approach to narration provided by those saved from extermination. Bronisława Szwajca wrote:

The story I am about to present is unique to me, although I know that each of us, the children of the Holocaust, treats his or her saving in this way because we all have survived thanks to some quaint fortune. I owe my life to luck, accident [underlined by R.K.], my mother's courage, and first of all to the unselfish help offered by many noble people [II 196].

In his Postowie (epilogue) to the first volume of memories Jerzy Ficowski also refers to accident:

This is a fragmented collection of our own biographies, whose prologue was supposed to be at the same time an inevitable epilogue. If something else happened, then it was due to the unpredictability of fate, as a result of some extraordinary entanglement of lucky accidents accompanied friendlily by a desperate will to survive and occasional human kindness rushing to help at moments when it was brave enough to be itself against the overwhelming evil and crime [I 268].

The terminology appearing in this narration as well as some kind of fictional arrangements, especially if one reads memories en masse, lead to the conviction that a certain topos has been created, which is understood as a recurring event, also at the level of language and semantics. Hanna Krall best demonstrates this repeatability in one of her texts; after a series of fragmented narratives related to salvation have been enumerated, i.e. a concrete event saving another person, there comes a kind of summary: "et cetera, in one thousand and five hundred variants" 8 .

\section{Distance and interpretation}

As mentioned before, in my discussion I make use of both various forms of personal documents and literary fiction. However, with respect to the former, I take interest in narration - understood as a coherent story about events, and as for the latter - I am interested in the biographical context (backup) of such fiction. And what is the most important is the approach to memory in a given text - the temporal distance from the narrated events at which the speaker situates himself / herself will be of special importance

\footnotetext{
${ }^{8}$ H. Krall, Dowody na istnienie, Wydawnictwo a5, Poznań 1996, p. 62.
} 
on all occasions. As for the reflection on the role of accident in a story about past events, distance has a very significant function because it is only from a time perspective that concrete events can be interpreted as accidental. Besides, the juxtaposition of a personal document and literature as well as of a record of an experience and fiction makes a kind of aporia only too visible. In narratives about extermination, especially in narratives about salvation from extermination understood as a system, the borderline between fiction and a factographic story about fortunes very often becomes vague. To present an example, in Hanna Krall's reportages many a time there appears a statement (articulated mainly by subsequent protagonists) that what happened is beyond any human comprehension and salvation itself - probably thanks to a series of accidents - was so unbelievable that it was impossible, or possible only in a novel. In his renowned study Alvin H. Rosenfeld wrote extensively about blurring the borderline between a document and fiction in the context of Jews' war-time experiences and about the need to strengthen a document with literature (so that language could bear this topic) and fiction with theory as well as history (so that people are able to believe this) ${ }^{9}$.

The note about distance as a necessary condition for a given event to be called an accident needs complementation. This is an important reference to a dual cognitive perspective adopted in systemics. Thus, the perspective of a saved child (running away or hiding) is, as it were, a fragmented perspective. A child can see details and - most importantly - is not able to predict what is about to follow. The results of research on the trauma of the children of the Holocaust who, as it turned out, were able to remember a great deal of minute details, are significant in this context. Constant hiding, controlling the environment and even their own behaviors fixed those elements in their memory ${ }^{10}$.

The later narration (from the perspective of an adult) about those events is equipped with a comprehensive knowledge about what happened later. Consequently, minute details, insignificant episodes or objects seen from this perspective are very often defined as accidents that are credited with a value determining survival. A quotation from Czarne sezony, which is a book of memories written by Michał Głowiński, a proclaimed Polish expert in the theory of literature who has been saved from extermination, will be especially telling as it is marked with a great deal of reflection on the mechanism of fate as a plot.

${ }^{9}$ A.H. Rosenfeld, Podwójna śmierć. Rozważania o literaturze Holocaustu [A Double Dying. Reflections on Holocaust Literature], transl. by B. Krawcowicz, Wydawnictwo Cyklady, Warszawa 2003, p. 122.

${ }^{10}$ Cf. J. Kowalska-Leder, Dzieciństwo czasu Zagłady. Przeciwstawne projekty prawdy, pamięci i zapisu tego doświadczenia, „Studia Judaica” 2005, no. 1-2, p. 175. 
When I now think of hiding on the Aryan side, about escaping from death, I am puzzled about to what extent accident played a role in this [underlined by R.K.]. A lucky, or sometimes apparently lucky or unlucky, accident decided about survival or annihilation, about life or death. An accident is momentary and not only unexpected (all accidents are unexpected), but surprising, irrational, and at variance with all the principles of probability. It is all the more unpredictable because it crystallizes in the world governed by the principles of strict determinism - one was not in the position to decide whether or not to become a Jew. How very often it was nothing but accident that decided about life or death. It weighed on human fate to a much greater extent than in spells of peace, when determinism had less say ${ }^{11}$.

\section{Systemics and ethics}

One of the more important motifs in the reflection on the Holocaust is a certain paradox - there is a great difference between the stories of the saved, especially those read in certain anthologies and configurations, and the systemic nature of extermination ${ }^{12}$. There is no place here for discussion about the effectiveness, totality and "rationality" of the Nazi ideology that would often embrace elements of improvisation, irrationalism or human madness ${ }^{13}$. However, those individual cases of salvation, especially when multiplied, make this system even more "exceptional" than it is customarily believed. It is in the context of the systemic character of extermination that individual cases of salvation are often called accidents.

The most important element of these reflections is the second part of the paradox, i.e. between the story of a saved person (only one individual and unique person) and some kind of repeatability as well as a schematic history of salvation that makes up a pattern. Thus, on the one hand, novelists themselves (often also the saved ones) try to underscore this singularity on many occasions. For example, Henryk Grynberg, who often makes use of personal narration, in his later Memorbuch broke his experience into a number of "name" stories, in which it would be possible to keep individual biographies ${ }^{14}$. On the other hand, narratives talking about salvation from extermination could be treated as a genre and a model at the same time. In structuralist terms, the genre of those narratives will be visible in the repeatability of a certain narrative template, especially in stressing an accident as an event determining salvation. Within the meaning of a system, it is possible to treat

${ }^{11}$ M. Głowiński, Czarne sezony, Wydawnictwo Literackie, Kraków 2002, p. 104.

12 Cf. A.H. Rosenfeld, Podwójna śmierć..., op. cit., pp. 54-55.

13 Cf. S. Buryła, Opisać Zagładę. Holocaust w twórczości Henryka Grynberga, Wydawnictwo Uniwersytetu Wrocławskiego, Wrocław 2006, pp. 31-32.

${ }^{14}$ Cf. H. Grynberg, Memorbuch, W.A.B., Warszawa 2000; A. Ubertowska, Aporie, skandale, wyrwy w tekście. Etyka opowieści o Zagładzie, „Teksty Drugie” 2002, no. 1-2, p. 136. 
this repeatability as a certain model - of all narratives of this kind, also those unspoken, but certified by salvation.

The Holocaust was a system, but only when seen from the perspective of the perpetrators. From the perspective of the victims who were intended for systemic annihilation, it was a time of unspeakable absurdity, of laws that could not be explained and an external force (circumstances) one had to succumb to for unknown reasons. This perspective - in addition to the deep tragedy that touched many millions of human beings - is expressed in a philosophical question asked by the victims about the meaning of the world which they did not invent, but which someone approved of. Memories (and fictitious stories) about salvation from extermination offer one answer to this question about the "meaning". Each of these narratives constitutes a single attempt at saving one's fate, whereas all of them make up a model that can be construed from a systemic perspective, which is now understood differently. If, as Alan Milchman and Alan Rosenberg maintain, "experimental thinking about the Holocaust" is about attempts at "seizing both the role of the accidental as well as the multitude of cause and effect chains that criss-crossed themselves to produce das Ereignis Auschwitz"15, then narratives about accidental saving from extermination would make up a ready-made exemplification of this philosophical hypothesis.

Obviously, the history of extermination also includes cases that cannot be included in narration about salvation because - on the contrary - they led to death. But those, as we know, have never been told... or they have - but by someone else. Narratives by the saved (and about salvation) present only cases that have contributed - in the systemic context - to salvation. Jerzy Ficowski points to this difference in the above-quoted Postowie:

The short records gathered here differ from all those unfixed, lost in silence, killed autobiographies first of all by the fact that they refer to the living, to those who, having crossed the fields of non-culpable ordeal, are with us. The fact that they have managed to save their lives, being wounded by orphanhood and pain, makes their narratives - against all odds - the accounts of the chosen, of those chosen by cruel fate that has involuntarily missed them ${ }^{16}$.

The use of both structuralist and systemic tools in the analysis of narration about being saved from extermination eventually leads to ethical questions. The theory of literature has, in a way, already settled accounts with orthodox narratology, which - in quest for principles, templates and models - has proved to be insensitive to individual speech. The structural theory of a story fell down because literature was shifted backwards in those studies. Matters are even more complicated in the context of the issues discussed here because,

${ }^{15}$ Eksperymenty..., op. cit., p. 46.

${ }^{16}$ J. Ficowski, Posłowie, vol. I, in: Dzieci Holocaustu mówiq..., op. cit., p. 268. 
even if one disregards the different degree of fiction in the post-Holocaust narration, they refer to personal traumas and an event which was unprecedented in history and with the consequences of which we have been struggling up to the present day, irrespective of the calculable losses.

After World War II, first they asked whether any art after / about the Holocaust was at all possible. Then they also asked what kind of art was possible and whether any type of decorum was there. How far can this boundary be pushed and who / what is responsible for this shift? A number of such questions provoked comic representations of extermination, and also the comic strip Maus. A Survivor's Tale by Art Spiegelman and, in Poland, Zbigniew Libera's work Lego. Obóz koncentracyjny.

The question about the systemic character of the narratives of the saved is just one of the many to follow, but it becomes shifted to the theoretical level: how can one study accounts about salvation from extermination? The basic ethical problem lies in singling out a certain kind of aporia. On the one hand, a template appears in those memories that can be easily worked out according to the guidelines of the structural theory of narrative. On the other hand, even the most fictional memories turn on a warning light: human fate and the fate of Jews in the $20^{\text {th }}$ century in general cannot be comprehended by any means. This means that the system was on the side of death, not salvation.

Even the "plot" of the fate of saved individuals is still unspeakable and unique. Perhaps the bottom line is this: an accident which is so often described as a saving accident becomes included in the narration about one, individual, i.e. "my" fate. In addition to the above quotations one can refer here to the statement by Maria Orwid, the world's leader in research on post-traumatic stress disorder (PTSD). Orwid stresses that the goal of this type of therapy is to "change narration from the tale of a victim to the narration of a strong person because survival and salvation were not a passive process, but they demanded active involvement"17.

To sum up, it needs to be reminded that accident in narration about being saved from extermination can be a saving event as it is described that way on many occasions in these narratives. When one looks at this from another perspective and realizes such a role of accident post factum, during narration, the feeling of guilt becomes stronger (I was saved by accident, but - if there had been a minor shift in the system - I would have died and the passer-by would have survived) and the nonsense of existence gets more self-evident (I live not "thanks to accident" but "by accident").

It seems, however, that the question about the ethics of systemic studies on narratives about salvation from extermination containing the theme

${ }^{17}$ M. Orwid, Przeżyć... I co dalej?, a conversation between Katarzyna Zimmerer and Krzysztof Szwajca, Wydawnictwo Literackie, Kraków 2006, p. 277. 
of a life-saving accident cannot be completely discarded for fear of abuse. The repeated pointing to accident here is independent and unintentional. In the above-quoted statements (and in many others) the conviction recurs that there exists repeatability (let me quote after Krall: "et cetera, in a thousand and five hundred variants"). An accident which happens again does not veil individual fate, but is rather an expression of the repeatability of the fate of humans who find themselves in a similar situation (systemic death) and yet become saved. Ervin Laszlo wrote, "each system, irrespective of how long it has existed, has had, throughout its existence, a specific structure defined by specific, fixed relationships taking place between and among its parts; it also has its own, irreducible characteristics" ${ }^{\prime 18}$.

\section{Kategoria przypadku w narracjach o ocaleniu z Zagłady}

\section{Streszczenie}

W artykule autor przedstawia przykłady polskich współczesnych narracji poholokaustowych (twórczość m.in. H. Krall, I. Fink, M. Głowińskiego, W. Dichtera, B. Wojdowskiego, świadectwa dzieci Holokaustu), ze szczególnym uwzględnieniem w nich kategorii przypadku. W większości tych tekstów przypadek rozpatrywany jest jako punkt zwrotny w narracji, zrywający fabułę wbrew wszelkim regułom - światopoglądowym czy historycznym, ale akceptowany ze względu na ocalający charakter. Głównym celem jest interpretacja owego egzystencjalnego i narracyjnego przypadku w świetle strukturalnej teorii narracji oraz próba odpowiedzi na pytanie o etykę takiej interpretacji. Z jednej bowiem strony, w narracjach ocalonych przypadek rzeczywiście powtarza się niemal jak refren, z drugiej - każda z tych narracji jest jednak zapisem pojedynczego losu, a samo zdarzenie ocalenia wymyka się wszelkiemu dyskursowi.

${ }^{18}$ E. Laszlo, Systemowy obraz świata, transl. by Urszula Niklas, PIW, Warszawa 1978, p. 37. 
